\title{
Lipid absorption and intestinal tumour incidence in rats fed on varying levels of calcium and butterfat
}

\author{
BY A. R. BEHLING, S. M. KAUP, L. L. CHOQUETTE AND J. L. GREGER* \\ Department of Nutritional Sciences, University of Wisconsin, 1415 Linden Drive, \\ Madison, WI 53706, USA
}

(Received 24 January 1990 - Accepted 6 April 1990)

\begin{abstract}
The purpose of the $2 \times 2$ factorial study was to determine the effect of varying levels of dietary calcium $(2.5$ and $10 \mathrm{~g} / \mathrm{kg})$ and butterfat $(50$ and $200 \mathrm{~g} / \mathrm{kg})$ on lipid utilization and on development of colon tumours in animals initiated with 1,2-dimethylhydrazine dihydrochloride. Among rats fed on $200 \mathrm{~g}$ butterfat $/ \mathrm{kg}$, the fourfold increase in $\mathrm{Ca}$ intake induced more than a sevenfold increase in faecal excretion of total lipids and almost a fortyfold increase in faecal excretion of acid-extractable lipid. Among rats fed on $50 \mathrm{~g}$ butterfat $/ \mathrm{kg}$, the ingestion of supplemental $\mathrm{Ca}$ had a less dramatic effect and induced only a twofold increase in faecal excretion of total lipids and a threefold increase in acidextractable lipid. The volume of intestinal adenocarcinomas was correlated with the excretion of acidextractable lipid in faeces $(R 0.369, P<0.02)$. Caecal enzymic activity was not correlated with tumour incidence or size or faecal lipid excretion. Overall, the fourfold increase in $\mathrm{Ca}$ intakes decreased total lipid absorption significantly but by less than $6 \%$.
\end{abstract}

Calcium : Lipid absorption: Butterfat: Rat

Ingestion of high-fat diets has been associated with increased tumourigenic events in both rodent and human colons (Rozhin et al. 1984; Willet \& MacMahon, 1984; Nauss et al. 1987). Maize oil or beef tallow were the fats given in the animal studies. We could find no carcinogenesis studies in which butterfat, which has a higher proportion of saturated shortand medium-chain triglycerides than maize oil or even beef tallow, was studied.

Ingestion of high levels of calcium has been associated with a lower incidence of colon carcinogenesis in several epidemiological studies (Slattery et al. 1988; Wargovich, 1988). In experimental studies, ingestion or even infusion of high levels of $\mathrm{Ca}$ reduced colon tumourigenesis in several (Wargovich et al. 1983; Appleton et al. 1987; Pence \& Buddingh, 1988) but not all studies (Kasprzak \& Waalkes, 1986; Bull et al. 1987; Gregorie et al. 1989).

One mechanism that might explain differences in results is that $\mathrm{Ca}$ reduces the incidence of cancer through the formation of insoluble salts (soap) with bile acids and free fatty acids (Newmark et al. 1984). Thus ingestion of high levels of dietary Ca would be hypothesized to be more effective in reducing tumourigenesis if fat intake were high. Early investigators observed that ingestion of high levels of $\mathrm{Ca}$ reduced fat absorption (Drenick, 1961; Fleischman et al. 1966). However, the excretion of soaps in the faeces of animals fed on varying levels of $\mathrm{Ca}$ and fat has not been quantified in controlled carcinogenesis studies.

Another mechanism by which $\mathrm{Ca}$ and butterfat may affect intestinal tumourigenesis is by changing the activity of microbial flora (Reddy et al. 1977). Moreover, it might be hypothesized that the formation of $\mathrm{Ca}$ soaps would form more substrate for caecal bacteria.

The purposes of the present experiment were (1) to quantify fat complexes in the faeces of rats fed on various levels of $\mathrm{Ca}$ and butterfat, (2) to assess the relationship of caecal flora 
activity to the changes in available substrate and (3) to assess whether these changes in $\mathrm{Ca}$ and fat intake and fat excretion were related to the development of intestinal tumours in 1,2-dimethylhydrazine dihydrochloride (DMH)-initiated rats.

\section{MATERIALS AND METHODS}

\section{Animals and diets}

Weanling male rats (112) were assigned to one of four dietary treatments that differed in their level of calcium $(2.5$ or $10 \mathrm{~g} / \mathrm{kg})$ and butterfat $(50$ or $200 \mathrm{~g} / \mathrm{kg})$. The dietary treatments were: the basal low-fat (LF) and high-fat (HF) diets that provided $2.5 \mathrm{~g} \mathrm{Ca} / \mathrm{kg}$ and the $\mathrm{Ca}-$ supplemented low-fat diet (HCaLF) and high-fat diet (HCaHF) that provided $10 \mathrm{~g} \mathrm{Ca} / \mathrm{kg}$.

The basal low-fat diet was similar in formulation to the AIN-76 diet (American Institute of Nutrition, 1977) except that butterfat was the source of fat and the Ca level was half that recommended. All diets were supplemented with $10 \mathrm{~g}$ maize oil $/ \mathrm{kg}$ to prevent essential fatty acid deficiency (Table 1). Diets were designed to ensure that the rats in each of the four treatments, on average, consumed equal amounts of energy and all nutrients, except lipid and $\mathrm{Ca}$. The diets were formulated using mass-energy balance equations so that energy contents of low-fat and high-fat diets were 16.23 and $19.12 \mathrm{~kJ} / \mathrm{g}$ diet respectively (Felder \& Kosseau, 1978). At the beginning of the study, rats were assigned by weight to twenty-eight blocks; there was one animal from each treatment in each block. In each block, rats were given $85 \%$ (by weight) as much of the high-fat diets as consumed by rats in the block fed on low-fat diets $a d$ lib. The rats fed on the high-fat diets ate all their dietary allotments. Accordingly, the average energy intake of all rats over the entire experimental period was 1020 (SE 8.4) kJ (244 (SE 2) kcal)/d.

Weanling male Sprague-Dawley rats (Harlan/Sprague-Dawley, Indianapolis, IN) were housed individually in stainless-steel wire-bottomed cages. The facilities met the standards of the American Association for Accreditation of Laboratory Animal Care. Deionized water was offered ad lib. Rats were weighed once weekly.

Beginning 2 weeks after rats were started on test diets, twenty rats per diet were injected subcutaneously $(15 \mathrm{mg} / \mathrm{kg}$ body-weight) with DMH (Sigma Chemical Company, St Louis, $\mathrm{MO}$ ) in saline ( $9 \mathrm{~g}$ sodium chloride/1) with $0.001 \mathrm{~m}$-EDTA adjusted to $\mathrm{pH} 6.8$. The remaining rats were injected subcutaneously with buffer only. Rats were injected weekly for 20 weeks. This protocol for intestinal tumour induction is consistent with that used by many other investigators (Goldin \& Gorbach, 1981; Freeman, 1986; Pence \& Buddingh, 1988).

\section{Sample collection and analyses}

Rats were fasted overnight, anaesthetized and killed by exsanguination $33-36$ weeks after initiation of the study. The rats were killed on a staggered schedule (i.e. nine or ten rats $\mathrm{killed} /$ treatment per $\mathrm{d}$ with the $3 \mathrm{~d}$ separated by 1 week) so that samples could be processed efficiently. A few ( $n 8)$ animals that became very ill were killed before week 33 . Number, location and size of all tumours were documented at autopsy with the help of a veterinary pathologist. All tumours were characterized histologically by defined standards (Ward, 1974).

Caecums of rats were tied off, excised and placed in an anaerobe chamber (Coy Laboratory Products Inc., Ann Arbor, MI) where the caecal contents were removed and diluted with $5-7 \mathrm{ml}$ buffer $(0.1 \mathrm{M}$-sodium phosphate buffer, saline, $\mathrm{pH} 7.4)$. The diluted caecal matter was transferred to sealed centrifuge tubes and centrifuged at $4^{\circ}$ at $1500 \mathrm{~g}$ for 15 $20 \mathrm{~min}$. The resulting caecal suspension was analysed for $\beta$-glucuronidase ( $E C$ 3.2.1.31; Shiau \& Chang, 1983) and nitroreductase (Wise et al. 1982) by standard methods in the anaerobe chamber. The activity of $\beta$-glucuronidase was expressed as units which 
Table 1 Composition of diets $(\mathrm{g} / \mathrm{kg})$ that contain low and high levels of butterfat with $2.5 \mathrm{~g}$ calcium $/ \mathrm{kg}$ (diets $\mathrm{LF}$ and $\mathrm{HF}$ ) or $10 \mathrm{~g} \mathrm{Ca} / \mathrm{kg}$ (diets $\mathrm{HCaLF}$ and $\mathrm{HCaHF}$ )

\begin{tabular}{|c|c|c|c|c|}
\hline \multirow[b]{2}{*}{ Component } & \multicolumn{2}{|c|}{ Low fat } & \multicolumn{2}{|c|}{ High fat } \\
\hline & LF & HCaLF & $\mathrm{HF}$ & $\mathrm{HCaHF}$ \\
\hline Casein* & $200 \cdot 0$ & $200 \cdot 0$ & $235 \cdot 0$ & $235 \cdot 0$ \\
\hline DL-Methionine* & $3 \cdot 0$ & 3.0 & $3 \cdot 5$ & $3 \cdot 5$ \\
\hline Sucrose & $200 \cdot 0$ & $200 \cdot 0$ & $235 \cdot 0$ & $235 \cdot 0$ \\
\hline Maize oil $\dagger^{\dagger}$ & $10 \cdot 0$ & $10 \cdot 0$ & 100 & $10 \cdot 0$ \\
\hline Butterfat, anhydrous* & $50 \cdot 0$ & $50 \cdot 0$ & $200 \cdot 0$ & $200 \cdot 0$ \\
\hline Cellulose* & $50 \cdot 0$ & $50 \cdot 0$ & $58 \cdot 5$ & $58 \cdot 5$ \\
\hline Vitamin mixture, AIN-76* & $10 \cdot 0$ & $10 \cdot 0$ & $11 \cdot 7$ & $11 \cdot 7$ \\
\hline $\begin{array}{l}\text { Mineral mixture, modified } \\
\text { AIN-76 }\end{array}$ & $35 \cdot 0$ & $35 \cdot 0$ & $41 \cdot 0$ & $41 \cdot 0$ \\
\hline Choline bitartrate* & $2 \cdot 0$ & $2 \cdot 0$ & $2 \cdot 3$ & $2 \cdot 3$ \\
\hline Calcium carbonate $\$$ & - & $18 \cdot 75$ & - & $22 \cdot 0$ \\
\hline Maize starch & $440 \cdot 0$ & $421 \cdot 25$ & $203-0$ & $181 \cdot 0$ \\
\hline
\end{tabular}

* Teklad Test diets (Madison, WI).

$\dagger$ Mazola corn oil (Best Foods, Englewood Cliffs, NJ).

Supplies (mg/kg diet): sodium chloride 2590 , calcium phosphate dibasic 8750 , potassium citrate monohydrate 7700 ; potassium sulphate 1820 , magnesium oxide 840 , manganous carbonate 123 , ferric citrate 140 , zinc carbonate 28 , cupric sulphate $10 \cdot 5$, potassium iodate $0 \cdot 35$, sodium selenite $0 \cdot 35$, chromium potassium sulphate $19 \cdot 2 ; 9135$ mg sodium orthophosphate monohydrogen $/ \mathrm{kg}$ diet was added to the mineral mixture to replace an additional $8750 \mathrm{mg}$ calcium phosphate dibasic (calcium source) $/ \mathrm{kg}$ omitted from the standard formulation.

$\S$ Mallinckrodt Inc. (Paris, KY).

were equivalent to $\mu \mathrm{g}$ phenolphthalein produced $/ \mathrm{h}$. Nitroreductase activity was expressed as units which were equivalent to nmol aminobenzoate produced/h. Protein contents of the caecal suspensions were determined by the method of Lowry et al. (1951).

Faeces were collected on days 26-28 from fifteen rats (ten DMH-treated and five placebo-treated rats) per treatment. Faecal lipids were extracted from freeze-dried faeces (Bligh \& Dyer, 1959; Sukhija \& Palmquist, 1988). Faeces were mixed with chloroform-methanol $(2: 1, \mathrm{v} / \mathrm{v})$, then additional chloroform, methanol, chloroform again and water were added in the following ratio $(1: 2: 1: 1)$; thorough mixing followed each addition. The mixture was filtered, the fitrate was allowed to separate and the organic fraction was dried and weighed; this fraction was called the neutral lipid fraction. The filtered solids were mixed with hydrochloric acid $(250 \mathrm{ml} / 1)$ in deionized water; then chloroform, methanol and finally water were added alternately as before and mixed. The second extraction mixture was filtered, the filtrate was allowed to separate and the organic fraction was dried and weighed; this fraction was called the acid-extractable lipid fraction. The total lipid was calculated to be the sum of the neutral- and acid-extractable lipid fractions.

Total lipids (sum of neutral- and acid-extractable fractions) were determined in low( $n$ 6 replicates) and high-fat diets $(n 6)$ and found to be 7.5 (SE $0 \cdot 3)$ and 22.2 (SE 0.5)\%, respectively. Known quantities of oleic acid (an example of a long-chain fatty acid), trilauric acid (an example of a triacylglycerol) and butyric acid (an example of a short-chain fatty acid) were added to faeces (three replicates for each addition) and the faeces were treated as described previously. Recoveries of these compounds were found to be $(\%)$ : oleic acid 88 (SE 8), trilauric acid 100 (SE 6), butyric acid 6 (SE 2). Thus, this methodology is very good for recovery of triacylglycerols and long-chain fatty acids but will not recover watersoluble, unesterified short-chain fatty acids. 
Percentage digestibility was calculated by the formula: ((dried feed intake - dried faecal weight $) \div$ dried feed intake) $\times 100$. Feed efficiency ratios were calculated by the formula: (weight gain $(\mathrm{g}) \div$ energy intake) $\times 100$.

\section{Statistical analysis}

The effects of dietary treatments and of DMH were evaluated within the framework of general linear models for analysis of variance (SAS Institute Inc., 1985). The effect of the treatments on faecal losses of lipids and faecal enzyme activity were factored into effects due to blocks, $\mathrm{DMH}$, variations in levels of dietary $\mathrm{Ca}$ and variations in levels of dietary fat. The effect of the treatments on tumour incidence was analysed using the chi-square test of homogeneity; the effect of the treatments on tumour number and size was analysed using Kruskal-Wallis (non-parametric) tests.

\section{RESULTS}

Rats fed on the high- $(200 \mathrm{~g} / \mathrm{kg})$ butterfat diet with moderate amounts $(2.5 \mathrm{mg} \mathrm{Ca} / \mathrm{g} \mathrm{diet})$ of $\mathrm{Ca}$ were larger $(P<0.05)$ than rats fed on the other diets throughout the study except at weeks 1 and 10, even though average energy intakes of rats in the four treatment groups were the same (Fig. 1). This difference in body weights of rats reflects differences in feed efficiency (Table 2$)$. Rats fed on the $200 \mathrm{~g}$ butterfat $/ \mathrm{kg}$ diet utilized feed slightly $(P<0.05)$ more efficiently than rats fed on $50 \mathrm{~g}$ butterfat $/ \mathrm{kg}$. However, increases in either the $\mathrm{Ca}$ or butterfat content of the diet were associated with decreased $(P<0.0001)$ diet digestibility.

Increased $\mathrm{Ca}$ intake not only reduced the total diet digestibility but also reduced $(P<$ $0.001)$ the apparent absorption of fat (Table 3). Thus rats, whether treated with DMH or the placebo, lost at least sevenfold more lipid in their faeces when fed on $200 \mathrm{~g}$ butterfat $/ \mathrm{kg}$ with high levels of $\mathrm{Ca}(\mathrm{HCaHF})$ than when fed on the moderate amount of Ca with 50 or $200 \mathrm{~g}$ butterfat $/ \mathrm{kg}$ diets (LF or HF).

Rats injected with DMH excreted less neutral-extractable $(P<0 \cdot 01)$ and acid-extractable $(P<0.005)$ lipid than rats injected with buffer only. Elevation of dietary $\mathrm{Ca}$ content increased $(P<0.0001)$ excretion of both neutral- and acid-extractable lipids in faeces. Elevation of dietary fat increased excretion of both neutral- and acid-extractable lipids in faeces only when the high level of $\mathrm{Ca}$ was given. Rats fed on diet HCaHF excreted almost fortyfold more acid-extractable lipid daily but only two- to threefold more neutralextractable lipid daily than rats fed on diet HF. This dramatic increase in acid-extractable lipid excretion by rats fed on diet HCaHF caused large differences in the relative composition of faecal lipid. Rats fed on diet LF excreted predominantly (86-87\%) neutralextractable lipid; rats fed on diet $\mathrm{HCaHF}$ excreted predominantly (67-68\%) acidextractable lipid.

This change in the distribution of faecal lipids from the neutral- to acid-extractable fractions corresponded with the higher tumour incidence in animals fed on diet $\mathrm{HCaHF}$ (Table 4). Chi-square analyses indicated that dietary $\mathrm{Ca}(P<0.173)$ and dietary fat $(P<$ $0.069)$ tended to affect tumour incidence. The dietary treatments did not significantly affect the number of tumours per animal or tumour volume. Tumour volume per animal was correlated with the amount of acid-extractable lipid excreted daily (Pearson correlation factor, $R 0.369, P<0.02$ ) and with the percentage of faecal lipid in the acid-extractable fraction (Pearson correlation factor, $R \quad 0.381, P<0.02$ ). All intestinal tumours were classified as adenocarcinomas by the veterinary pathologist.

Caecal microbial activity and mass did not correlate with any of the measures of tumour development or lipid composition of faeces (Table 5). Rats injected with DMH had larger 


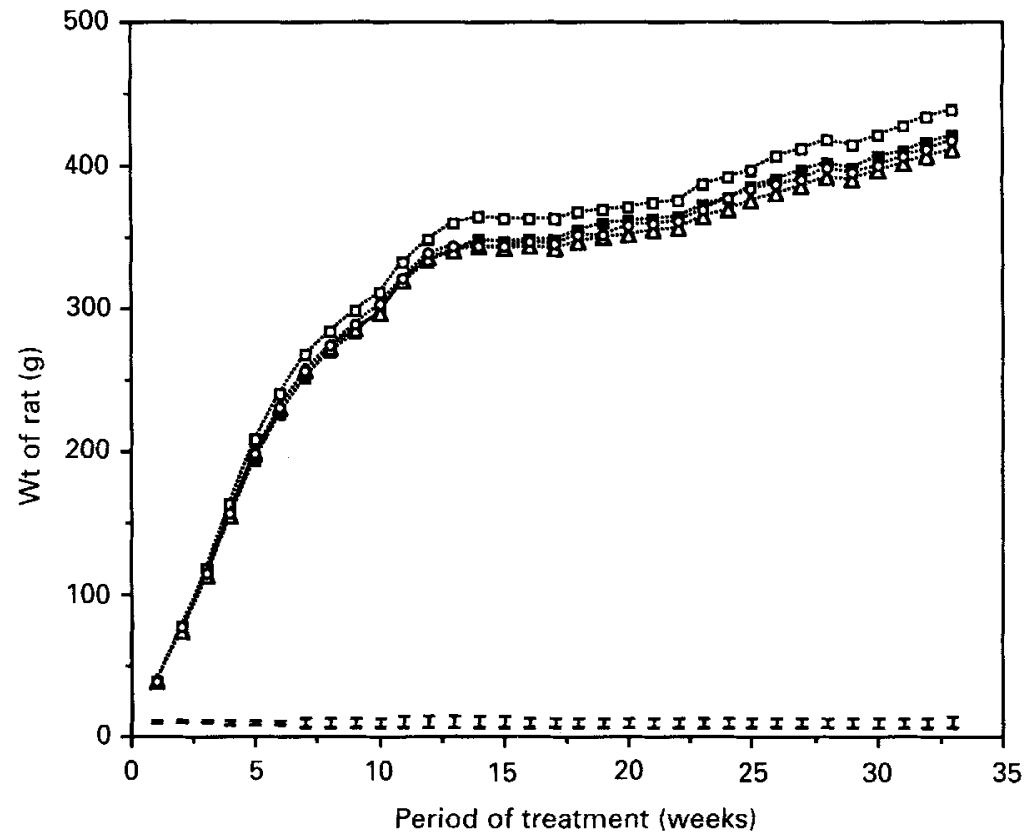

Fig. 1. Rats fed on high levels of butterfat (diet HF; $\square---\square)$ were significantly larger $(P<0.05)$ than rats fed on low levels of butterfat (diet LF; O-- O), or either level of fat with the high level of calcium (diet HCaLF; $\triangle \cdots \triangle$ or diet HCaHF; $---\square)$ at all time-points except weeks 1 and 10. Values are means, with their standard errors represented by vertical bars at the bottom of the figure, for twenty-eight rats; 1,2-dimethylhydrazine dihydrochloride- and placebo-treated rats combined.

Table 2. Feed utilization of rats fed on two levels of butterfat (diets LF and HCaLF v. HF and $H C a H F$ ) and two levels of calcium (diets $L F$ and $H F$ v. HCaLF and HCaHF) and injected with 1,2-dimethylhydrazine dihydrochloride $(D M H)$ or placebo solutions*

(Mean values for twenty rats for DMH treatment and eight rats for placebo treatment)

\begin{tabular}{|c|c|c|c|}
\hline Carcinogen & Diet & $\begin{array}{l}\text { Feed conversion } \\
\text { efficiency }(\mathrm{g} \text { wt } \\
\text { gain } / 100 \mathrm{~kJ})\end{array}$ & $\begin{array}{c}\text { Diet } \\
\text { digestibility } \dagger \\
(\%)\end{array}$ \\
\hline \multirow[t]{4}{*}{ DMH } & $\mathrm{LF}$ & $11 \cdot 7$ & $94 \cdot 3$ \\
\hline & $\mathrm{HF}$ & $12 \cdot 2$ & $93 \cdot 0$ \\
\hline & HCaLF & $11 \cdot 7$ & 91.8 \\
\hline & $\mathrm{HCaHF}$ & $12 \cdot 0$ & $89 \cdot 0$ \\
\hline SEM & & 0.08 & $0 \cdot 13$ \\
\hline \multirow{4}{*}{ Placebo } & $\mathrm{LF}$ & $12 \cdot 3$ & $94 \cdot 2$ \\
\hline & $\mathrm{HF}$ & $12 \cdot 8$ & $93 \cdot 3$ \\
\hline & HCaLF & $12 \cdot 1$ & $91 \cdot 5$ \\
\hline & $\mathrm{HCaHF}$ & $12 \cdot 5$ & 87.5 \\
\hline \multirow[t]{3}{*}{ SEM } & & $0 \cdot 13$ & $0 \cdot 21$ \\
\hline & \multicolumn{3}{|c|}{ Statistical effects as determined by analyses of variance } \\
\hline & - & $P<0.0005$ & NS \\
\hline Diet $\mathrm{Ca}$ & - & NS & $P<0.0001$ \\
\hline Diet fat & - & $P<0.05$ & $P<0.0001$ \\
\hline
\end{tabular}

NS, not significant.

* For details of treatments and dietary regimens, see p. 506 and Table 1.

$\dagger(($ Diet intake $-\mathrm{g}$ faeces $) \div$ diet intake $) \times 100$; faecal collection during week 4 of study. 
Table 3. Faecal lipid excretion of rats after being fed on two levels of butterfat (diet LF and $H C a L F$ v. $H F$ and $H C a H F$ ) and two levels of calcium (diets $L F$ and $H F$ v. HCaLF and $H C a H F)$ and injected with 1,2-dimethylhydrazine dihydrochloride (DMH) or placebo solutions*

(Mean values for ten rats for DMH treatment and five rats for placebo treatment)

\begin{tabular}{|c|c|c|c|c|c|c|c|}
\hline \multirow[b]{2}{*}{ Carcinogen } & \multirow[b]{2}{*}{ Diet } & \multicolumn{2}{|c|}{ Total lipid } & \multicolumn{2}{|c|}{ Faecal neutral lipid } & \multicolumn{2}{|c|}{$\begin{array}{c}\text { Faecal acid-extract- } \\
\text { able lipid }\end{array}$} \\
\hline & & $\begin{array}{c}\text { Apparent } \\
\text { absorption } \\
(\%)\end{array}$ & $\begin{array}{c}\text { Faecal } \\
\text { losses } \\
(\mathrm{mg} / \mathrm{d})\end{array}$ & $(\mathrm{mg} / \mathrm{d})$ & $\begin{array}{l}\% \text { of total } \\
\text { lipid }\end{array}$ & $(\mathrm{mg} / \mathrm{d})$ & $\begin{array}{l}\% \text { of total } \\
\text { lipid }\end{array}$ \\
\hline \multirow[t]{4}{*}{$\mathrm{DMH}$} & LF & $97 \cdot 3$ & 27 & 23 & 86 & 4 & 14 \\
\hline & $\mathrm{HF}$ & $99 \cdot 1$ & 30 & 26 & 86 & 4 & 14 \\
\hline & HCaLF & 93.9 & 57 & 42 & 72 & 15 & 28 \\
\hline & $\mathrm{HCaHF}$ & $93 \cdot 1$ & 223 & 70 & 32 & 153 & 68 \\
\hline SEM & & 0.55 & $13 \cdot 9$ & $4 \cdot 3$ & $3 \cdot 7$ & $10 \cdot 5$ & $3 \cdot 7$ \\
\hline \multirow[t]{4}{*}{ Placebo } & $\mathrm{LF}$ & $96 \cdot 8$ & 35 & 30 & 87 & 5 & 13 \\
\hline & $\mathrm{HF}$ & 99.0 & 38 & 32 & 86 & 6 & 14 \\
\hline & HCaLF & 93.9 & 66 & 47 & 72 & 19 & 28 \\
\hline & $\mathrm{HCaHF}$ & $90 \cdot 8$ & 350 & 114 & 33 & 236 & 67 \\
\hline \multirow[t]{2}{*}{ SEM } & & $0 \cdot 78$ & 31.9 & $8 \cdot 5$ & $5 \cdot 1$ & $23 \cdot 7$ & $15 \cdot 1$ \\
\hline & \multicolumn{6}{|c|}{ Statistical effects as determined by analysis of variance } & \\
\hline $\mathrm{DMH}$ & - & NS & $P<0.005$ & $P<0.01$ & NS & $P<0.005$ & NS \\
\hline Diet $\mathbf{C a}$ & - & $P<0.0001$ & $P<0.0001$ & $P<0.0001$ & $P<0.0001$ & $P<0.0001$ & $P<0.0001$ \\
\hline Diet fat & - & NS & $P<0.0001$ & $P<0.0001$ & $P<0.0001$ & $P<0.0001$ & $P<0.0001$ \\
\hline
\end{tabular}

NS, not significant.

* For details of treatments and dietary regimens, see p. 506 and Table 1.

Table 4. Intestinal tumour development among 1,2-dimethylhydrazine dihydrochloride $(D M H)$-treated rats fed on two levels of butterfat (diets $L F$ and $H C a L F$ v. $H F$ and $H C a H F$ ) and two levels of calcium (diets LF and HF v. HCaLF and HCaHF)*

\begin{tabular}{|c|c|c|c|c|}
\hline Diet & $n^{\dagger}$ & $\begin{array}{c}\text { No. of tumour-bearing } \\
\text { animals } \\
(\% \text { of total })\end{array}$ & $\begin{array}{l}\text { No. of tumours } \\
\text { per tumour- } \\
\text { bearing animal }\end{array}$ & $\begin{array}{c}\text { Tumour volume per tumour- } \\
\text { bearing animal } \\
\left(\log 10 \mathrm{~mm}^{3}\right)\end{array}$ \\
\hline LF & 20 & 40 & $2 \cdot 6$ & $2 \cdot 83$ \\
\hline $\mathrm{HF}$ & 19 & 53 & $2 \cdot 0$ & 2.54 \\
\hline HCaLF & 19 & 47 & 1.6 & $2 \cdot 77$ \\
\hline $\mathrm{HCaHF}$ & 20 & 75 & $1 \cdot 5$ & 3.02 \\
\hline SEM & - & - & $0 \cdot 3$ & 0.14 \\
\hline
\end{tabular}

* For details of treatments and dietary regimens, see p. 506 and Table 1.

$\uparrow$ Only DMH-treated rats included; placebo-treated rats had no tumours. All tumours in DMH-treated rats were identified as adenocarcinomas by the pathologist.

$(P<0.0005)$ caccal mass and lower $\beta$-glucuronidase $(P<0.0001)$ and nitroreductase $(P<$ $0.005)$ activity than rats injected with the buffer solution only. In general, the dietary treatments did not have as dramatic an effect on caecal mass and microbial activity as they did on faecal lipid excretion. Rats given 200 rather than $50 \mathrm{~g}$ butterfat $/ \mathrm{kg}$ had reduced caecal mass $(P<0.05)$ and nitroreductase activity $(P<0.0001)$. Elevation of dietary $\mathrm{Ca}$ decreased $(P<0.05)$ caecal protein concentrations and this resulted in a increase $(P<$ $0.0001)$ in nitroreductase activity when expressed as $\mathrm{U} / \mathrm{mg}$ protein. 
Table 5. Caecal flora of rats fed on two levels of butterfat (diets LF and HCaLF v. HF and $H C a H F$ ) and two levels of calcium (diets $L F$ and $H F$ v. $H C a L F$ and $H C a H F$ ) and injected with 1,2-dimethylhydrazine dihydrochloride (DMH) or placebo solutions*

\begin{tabular}{|c|c|c|c|c|c|c|}
\hline Carcinogen & Diet & $n \dagger$ & $\begin{array}{l}\text { Caecal mass } \\
(\mathrm{g} / \mathrm{kg} \text { body- } \\
\mathrm{wt})\end{array}$ & $\begin{array}{c}\text { Protein } \\
\text { (mg/g contents) }\end{array}$ & $\begin{array}{c}\beta \text {-Glucuronidase }+ \\
\text { (units/mg pro- } \\
\text { tein) }\end{array}$ & $\begin{array}{l}\text { Nitroreductase } \$ \\
\text { (units/mg pro- } \\
\text { tein) }\end{array}$ \\
\hline \multirow[t]{4}{*}{ DMH } & LF & 19 & $6 \cdot 3$ & $17 \cdot 9$ & $65 \cdot 1$ & $35 \cdot 5$ \\
\hline & $\mathrm{HF}$ & 16 & $5 \cdot 3$ & $16 \cdot 6$ & $47 \cdot 4$ & $25 \cdot 6$ \\
\hline & HCaLF & 20 & $7 \cdot 0$ & 11.9 & $53 \cdot 1$ & $41 \cdot 5$ \\
\hline & $\mathrm{HCaHF}$ & 19 & $6 \cdot 2$ & $14 \cdot 6$ & $44 \cdot 1$ & $39 \cdot 5$ \\
\hline SEM & & & 0.23 & 0.88 & 3.41 & 1.40 \\
\hline \multirow[t]{4}{*}{ Placebo } & LF & 8 & $5 \cdot 2$ & $15 \cdot 1$ & $98 \cdot 7$ & 38.8 \\
\hline & $\mathrm{HF}$ & 8 & $3 \cdot 7$ & $14 \cdot 6$ & $90 \cdot 6$ & 30.6 \\
\hline & HCaLF & 6 & $4 \cdot 5$ & $11 \cdot 4$ & $91 \cdot 1$ & 53.0 \\
\hline & $\mathrm{HCaHF}$ & 8 & 40 & $10 \cdot 5$ & $85 \cdot 8$ & $46 \cdot 4$ \\
\hline \multirow[t]{2}{*}{ SEM } & & & 0.38 & 1.38 & 5.53 & $2 \cdot 27$ \\
\hline & & \multicolumn{4}{|c|}{ Statistical effects as determined by analysis of variance } & \\
\hline DMH & - & - & $P<0.005$ & NS & $P<0.0001$ & $P<0.005$ \\
\hline Diet $\mathrm{Ca}$ & - & - & NS & $P<0.05$ & NS & $P<0.0001$ \\
\hline \multirow[t]{2}{*}{ Diet fat } & - & - & $P<0.05$ & NS & NS & $P<0.01$ \\
\hline & 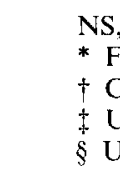 & $\begin{array}{l}\text { etai } \\
1 \text { en } \\
\exp \end{array}$ & $\begin{array}{l}\text { cant. } \\
\text { f treatments a } \\
\text { ne activity not } \\
\text { sed as } \mu \mathrm{g} \text { pher } \\
\text { sed as nmol ar }\end{array}$ & $\begin{array}{l}\text { dietary regimens } \\
\text { teasured in rats k } \\
\text { phthalein produc } \\
\text { lobenzoate produ }\end{array}$ & $\begin{array}{l}\text { ee p. } 506 \text { and Table } \\
\text { d before week } 33 \text {. } \\
/ \mathrm{h} \text {. } \\
\mathrm{d} / \mathrm{h} \text {. }\end{array}$ & \\
\hline
\end{tabular}

\section{DISCUSSION}

Among rats in the present study fed on a low-fat diet, a fourfold increase in Ca intake increased faecal excretion of total lipids by about twofold and increased faecal excretion of acid-extractable lipids by more than threefold without a change in intestinal tumour incidence. However, among rats given the high-fat diet the same increase in $\mathrm{Ca}$ intake induced more than a sevenfold increase in faecal excretion of total lipids, almost a fortyfold increase in faecal excretion of acid-extractable lipid, and tended to increase the incidence of intestinal adenocarcinomas. No similar additive effect of dietary $\mathrm{Ca}$ and fat was observed on caecal flora.

These findings are consistent with the observations of Gregoire et al. (1989). They found that subjects who previously had surgery for colorectal adenocarcinoma had elevated concentrations of deoxycholic acid in the aqueous phase of their faeces when they were given supplemental $\mathrm{Ca}$, but this was associated with no change in colon mucosal proliferation. Bull et al. (1987) reported that the addition of $\mathrm{Ca}(10 \mathrm{~g} / \mathrm{kg})$ to a high- $(300$ $\mathrm{g} / \mathrm{kg})$ fat diet but not a low- $(50 \mathrm{~g} / \mathrm{kg})$ fat diet increased the incidence of bowel tumour in rats treated with azoxymethane.

Together these findings with our findings suggest that the importance of $\mathrm{Ca}$ as a protective agent in colon tumourigenesis needs to be re-evaluated. Previously, Wargovich et al. (1983) have noted that supplemental Ca decreased the proliferative effects of fatty acids and bile acids on colon epithelium. At least two other groups of investigators also noted decreased intestinal tumour incidence among rats orally administered supplemental Ca (Appleton et al. 1987; Pence \& Buddingh, 1988).

A number of potentially important variations in the protocols of these studies could be responsible for the divergent results. One difference is the form of $\mathrm{Ca}$ give in the various studies. Calcium carbonate was given in the present study. Calcium gluconate and lactate 
(Wargovich et al. 1983; Appleton et al. 1987; Pence \& Buddingh, 1988) and calcium phosphate (Bull et al. 1987) were given in other studies. The form of Ca salt given will affect faecal pH. Behling \& Greger (1988) found that rats fed on calcium carbonate had a higher faecal $\mathrm{pH}$ than rats fed on yoghurt or calcium phosphate but lower $\mathrm{pH}$ than rats fed on an amino acid chelate of $\mathrm{Ca}$. These changes in $\mathrm{pH}$ could effect gut flora and the solubility of faecal bile acids and soaps.

A second difference in these studies is the type of dietary fat. Investigators gave maize oil (Pence \& Buddingh, 1988) or beef tallow (Bull et al. 1987), or instilled deoxycholic acid on colonic epithelium (Wargovich et al. 1983). In the present study, butterfat was used because $\mathrm{Ca}$ is found most often with butterfat in dairy products.

In a previous study, rats initiated with DMH and fed on $200 \mathrm{~g}$ butterfat with $10 \mathrm{~g} \mathrm{Ca} / \mathrm{kg}$ for 7 weeks had elevated caecal nitroreductase and $\beta$-glucuronidase activity and lowered diet digestibility (Behling et al. 1990). This suggested that during early promotion the availability of substrate (i.e. undigested dry matter) was correlated with caecal enzyme activity. However, the caecal flora of rats at the end of this present study were not correlated with the incidence or size of intestinal tumours or with faecal losses of dry matter and lipid after $26-28 \mathrm{~d}$.

In general, a fourfold change in Ca intake had dramatic effects on excretion of acidextractable lipid in faeces. However, the overall effect on percentage absorption of lipid, although statistically significant, was small, i.e. less than $6 \%$.

This research was supported by the College of Agricultural and Life Sciences, University of Wisconsin-Madison Project no. 2623, the National Institutes of Health Training Grant No. 5T32CA09451 and an Institutional Grant of the American Cancer Society. The authors wish to thank Gary Weaver DVM, PhD for the histopathology work in this study.

\section{REFERENCES}

American Institute of Nutrition (1977). Report of the American Institute of Nutrition ad hoc committee on standards for nutrition studies. Journal of Nutrition 107, 1340-1348.

Appleton, G. V. N., Davies, P. W., Bristol, J. B. \& Williamson, R. C. N. (1987). Inhibition of intestinal carcinogenesis by dietary supplementation with calcium. British Journal of Surgery 74, 523-535.

Behling, A. R. \& Greger, J. L. (1988). Mineral metabolism of aging female rats fed various commercially available calcium supplements or yogurt. Pharmacological Research 5, 501-505.

Behling, A. R., Kaup, S. M. \& Greger, J. L. (1990). Changes in intestinal function of rats initiated with DMH and fed varying levels of butterfat, calcium and magnesium. Nutrition and Cancer 31, 189-199.

Bligh, E. G. \& Dyer, W. J. (1959). A rapid method of total lipid extraction and purification. Canadian Journal of Biochemistry and Physiology 37, 911-917.

Bull, A., Bird, R. P., Bruce, W. R., Nigro, N. \& Medline, A. (1987). Effect of calcium on azoxymethane induced tumors in rats. Gastroenterology $\mathbf{9 2}, 1332$.

Drenick, E. J. (1961). The influence of ingestion of calcium and other soap-forming substances on fecal fat. Gastroenterology 41, 242 244.

Felder, R. M. \& Kosseau, R. W. (1978). Fundamentals of material balances. Elementary Principles of Chemical Processes, pp. 81-164. New York: John Wiley \& Sons.

Freeman, H. F. (1986). Effects of differing purified cellulose, pectin, and hemicellulose fiber diets on fecal enzymes in 1.2-dimethylhydrazine-induced rat colon carcinogenesis. Cancer Research 46, 5529-5532.

Fleischman, A. I., Yacowitz, H., Hayton, T. \& Bierenbaum, M. L. (1966). Effects of dietary calcium upon lipid metabolism in mature male rats fed beef tallow. Journal of Nutrition 88, 255-260.

Goldin. B. R. \& Gorbach, S. L. (1981). Effect of antibiotics on incidence of rat intestinal tumors induced by 1,2dimethylhydrazine dihydrochloride. Journal of the National Cancer Institute 67, 877-880.

Gregoirc, R. C., Stern, H. S., Yeung, K. S., Stadler, J., Langley, S., Furrer, R. \& Bruce, W. R. (1989). Effect of calcium supplementation on mucosal cell proliferation in high risk patients for colon cancer. Gut 30, 376-382.

Kasprzak, K. S. \& Waalkes, M. P. (1986). The role of calcium, magnesium and zinc in carcinogenesis. In Essential Nutrients in Carcinogenesis, pp. 497-515 [L. A. Poirier, P. M. Neuterne and M. W. Pariza, editors]. New York: Plenum Press.

Lowry, O. H., Rosebrough, N. J., Farr, A. L. \& Randall, R. J. (1951). Protein measurement with the folin phenol reagent. Journal of Biological Chemistry 193, 165-275. 
Nauss, K. M., Jacobs, L. R. \& Newberne, P. M. (1987). Dietary fat and fiber: relationship to caloric intake, body growth, and colon tumorigenesis. American Journal of Clinical Nutrition 45, 243-251.

Newmark, H. L., Wargovich, M. J.\& Bruce, W. R. (1984). Colon cancer and dietary fat, phosphate, and calcium: a hypothesis. Journal of the National Cancer Institute 72, 1323-1325.

Pence, B. C. \& Buddingh, F. (1988). Inhibition of dietary fat-promoted colon carcinogenesis in rats by supplemental calcium or vitamin $\mathrm{D}_{3}$. Carcinogenesis 9, 187-190.

Reddy, B. S., Mangat, S., Weisburger, J. H. \& Wynder, E. L. (1977). Effect of high-risk diets for colon carcinogenesis on intestinal, mucosal and bacterial $\beta$-glucuronidase activity in F344 rats. Cancer Research 37 , 3533-3536.

Rozhin, J., Wilson, P. S., Bull, A. W. \& Nigro, N. D. (1984). Ornithine decarboxylase activity in the rat and human colon. Cancer Research 44, 3226-3230.

SAS Institute Inc. (1985). SAS/STAT TM Guide for Personal Computers, version 6 ed., pp. 183-260. Cary, NC: SAS Institute Inc.

Shiau, S.-Y. \& Chang, G. W. (1983). Effects of dietary fiber on fecal mucinase and $\beta$-glucuronidase activity in rats. Journal of Nutrition 113, 138-144.

Slattery, M. L., Sorenson, A. W. \& Ford, M. H. (1988). Dietary calcium intake as a mitigating factor in colon cancer. American Journal of Epidemiology 128, 504-514.

Sukhija, P. S. \& Palmquist, D. L. (1988). Rapid method for determination of total fatty acid content and composition of feedstuffs and feces. Journal of Agricultural and Food Chemistry 36, 1202-1206.

Ward, J. M. (1974). Morphogenesis of chemically induced neoplasms of the colon and small intestine in rats. Laboratory Investigation 30, 505-513.

Wargovich, M. J. (1988). Calcium and colon cancer. Journal of American College of Nutrition 7, 295-300.

Wargovich, M. J., End, V. W. S., Newmark, H. L. \& Bruce, W. R. (1983). Calcium ameliorates the toxic effect of deoxycholic acid on colonic epithelium. Carcinogenesis 4, 1205-1207.

Willett, W. C. \& MacMahon, B. (1984). Diet and cancer - an overview, part 2. New England Journal of Medicine 310, 697-703.

Wise, A., Mallett, A. K. \& Rowland, I. R. (1982). Dietary fibre, bacterial metabolism and toxicity of nitrate in the rat. Xenobiotica 12,111-118. 